
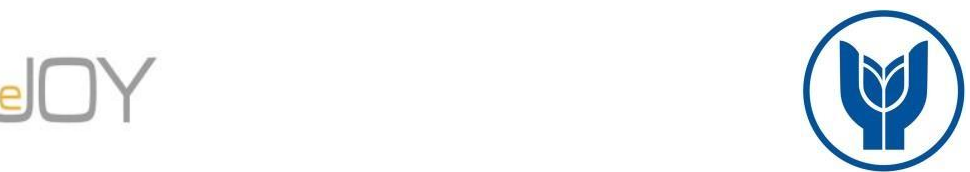

Ayçin, E., Çakın, E. / Journal of Yasar University, 2019, 14/55, 251-265

\title{
KOBİ'lerin Finansal Performansının MACBETH-COPRAS Bütünleşik Yaklaşımıyla Değerlendirilmesi
}

\section{Evaluation of Financial Performance of SMEs with MACBETH-COPRAS Integrated Approach}

\author{
Ejder AYÇİN, Kocaeli Üniversitesi, Türkiye, ejder.aycin@kocaeli.edu.tr \\ Enver ÇAKIN, KOSGEB, Türkiye, enver.cakin@kosgeb.gov.tr
}

\begin{abstract}
Öz: Tüm dünyada olduğu gibi ülkemizin de ekonomik ve sosyal kalknmasının temelini küçük ve orta büyüklükteki ișletmeler (KOBI) olușturmaktadır. KOBİ'lerin rekabet ortamında sürdürülebilir bir büyüme gerçekleştirebilmesi ve varliklarını devam ettirebilmesi için düzenli olarak performansların ölçmeleri gerekmektedir. Bu çallşmada BIST KOBI Endeksinde yer alan işletmelerin finansal performansları MACBETH-COPRAS yöntemlerinin birlikte kullanılması ile analiz edilmiștir. MACBETH yöntemi ile kriterler ağırlıklandırllmıș ve COPRAS yöntemi ile de finansal performans değerleri ve sıralamaları elde edilmiştir. MACBETH yöntemi sonuçlarına göre, en fazla öneme sahip kriterler aktif karlllık oranı, sațşların karlllık oranı ve cari oran iken; en az öneme sahip kriterler ise kaldıraç oranı, duran varlık devir hızı oranı ve dönen varllk devir hızı oranıdır. COPRAS yöntemine göre, finansal performansı en iyi olan işletmelerin RTA, Politeknik ve Vanet olduğu sonucuna ulaşılmıștır.
\end{abstract}

\section{Anahtar Sözcükler: KOBİ, Finansal Performans, MACBETH, COPRAS}

Abstract: Small and medium-sized enterprises (SMEs) form the basis of economic and social development in our country as in all over the world. SMEs need to measure their performance regularly in order to achieve sustainable growth and to sustain their existence in the competitive environment. In this study, the financial performances of the enterprises included in the BIST SME Index are analyzed by using the MACBETHCOPRAS methods. The criteria are weighted by the MACBETH method and financial performance values and rankings are obtained by COPRAS method. According to the results of the MACBETH, it is concluded that the most important criteria are return on assets, return on sales, and current ratio; the least important criteria are leverage ratio, current asset turnover ratio and fixed asset turnover ratio. According to the results of the COPRAS, the best performing enterprices are RTA, Politeknik and Vanet.

Keywords: SME, Financial Performance, MACBETH, COPRAS

\section{Giriş}

İşletmelerin büyük çoğunluğunu oluşturan ve ekonomilerin yapıtaşları olan KOBİ'ler ulusal ve uluslararası arenalarda her zaman önemli roller üstlenerek ülke ekonomilerinin gelişimine büyük katkılar sağlamıştır. Bu anlamda bir ülkedeki KOBİ'lerin üretim yetenekleri, teknolojik altyapı ve gelişim düzeyleri doğrudan ülkelerin ekonomik yapısını ve gücünü belirlemektedir. Ülkemiz için de sağlam ve sürekli gelişen bir ekonomiye sahip olmanın yolu, KOBI'lerin büyüyüp gelişmelerine ve uluslararası pazarlarda rekabet gücünü arttırmalarına bağlıdır.

KOBİ'ler sağladıkları istihdam, oluşturdukları yatırım ortamları, ürettikleri katma değerli ürünler ve önemli miktarda yaptıkları ihracatları ile ülkemizin büyümesine ve kalkınmasına ciddi yardımları olmaktadır. Ayrıca hız, esneklik ve çevresel değişimlere çok çabuk adapte olabilmeleri gibi önemli güçlü yönleri bulunmaktadır. Bunun yanı sıra KOBİ'lerin birçok zayıf noktası bulunmakta ve bu zayıf yönlerinin en başında finansman sorunları gelmektedir. KOBİ'ler finansmana erişim, sermaye yetersizliği, teminat sıkıntısı vb. gibi konularda ciddi sorunlar yaşamakta ve bu sorunlar KOBI'lerin üretim, pazarlama, Ar-Ge çalışmaları, teknolojik yatırım gibi birçok faaliyetini olumsuz yönde etkilemektedir. Bunu önlemek için KOBİ'ler satışlarını, karlılıklarını, yatırımların etkinliğini ve finans kaynaklarını verimli kullanıp kullanmadıklarını düzenli olarak analiz etmeli, hem yıllar itibariyle hem de rakipleriyle karşılaştırmalı olarak incelemeli ve gerekli önlemleri almalıdır.

$\mathrm{Bu}$ çalışmada, BIST KOBİ Endeksinde yer alan işletmelerin finansal performansları MACBETH-COPRAS çok kriterli karar verme (ÇKKV) yöntemlerinin entegre bir şekilde uygulanması ile ölçülmüştür. Problemde yer alan finansal kriterlerin ağırlıkları MACBETH yöntemi ile elde edilmiş, COPRAS yöntemi ile de işletmelerin finansal performans değerleri ve sıralamaları hesaplanmıştır. ÇKKV yöntemleri son yıllarda uygulamaları giderek artan, birbirleriyle çelişen kriterler altında en iyi alternatiflerin belirlenmesinde kullanılan, etkin ve tutarlı çözümler sunan yöntemlerdir. MACBETH ve COPRAS yöntemleri ile ilgili çalışmaların diğer ÇKKV yöntemlerine göre sayıca az olmasından dolayı bu çalışmanın ve bu çalışma kapsamında yapılan uygulamanın literatüre katkı sağlayacağı düşünülmektedir.

$\mathrm{Bu}$ düşünce ile çalışma dört bölümden oluşmaktadır. İlk bölümde finansal performans konusunda ÇKKV yöntemleri ile yapılan çalışmalara ve bu çalışmalarda hangi kriterlerin dikkate alındığına yönelik literatür taraması yapılmıştır. İkinci ve üçüncü bölümlerde çalışma kapsamında kullanılan MACBETH ve COPRAS yöntemlerinin teorik çerçevelerine ve uygulama aşamalarına yer verilmiştir. Son bölümde ise, yöntemlerin bütünleşik olarak kullanılarak işletmelerin finansal performanslarının ölçüldüğü uygulama kısmı aktarılmıştır. 


\section{Literatür Taraması}

Literatürde, ÇKKV yöntemlerini bütünleşik olarak kullanıldığı ve finansal performansın değerlendirildiği birçok çalışmaya rastlanılmaktadır. Bu başlık altında literatürde yer alan çalışmalar, ilgili çalışmada ele alınan finansal kriterler ve kullanılan yöntemler bakımından detaylı bir şekilde incelenmiştir.

Wang gri ilişkisel analiz ve bulanık TOPSIS yöntemlerini bir arada kullandığı çalışmasında finansal yapı, ödeme gücü, ciro ve karlılık kriterlerini dikkate alarak, üç farklı havayolu şirketinin finansal performanslarını değerlendirmiştir (Wang, 2008). Ertuğrul ve Karakaşoğlu, Borsa İstanbul'da endekslenen on beş çimento fabrikasının likidite, faaliyet, ekonomik yapı, karlılık ve büyüme oranlarını dikkate aldıkları çalışmalarında, bulanık AHP ve TOPSIS yöntemlerini bir arada kullanarak firmaların finansal performans sıralamalarını elde etmişlerdir (Ertuğrul ve Karakaşoğlu, 2009). Seçme vd., Türkiye'de faaliyet gösteren en büyük beş bankanın performanslarını finansal ve finansal olmayan kriterler göre değerlendirmişlerdir. Finansal performans kriterleri olarak sermaye yeterliliği, varlık kalitesi, likidite, karlılık, gelir yapısı, hisse durumu ve pazar payı kriterlerini dikkate almışlardır. Kriterlerin önem ağırlıklarını bulanık AHP ile hesaplayıp, bankaların performans sıralamalarını ise TOPSIS yöntemiyle elde etmişlerdir (Seçme vd., 2009). Wang, konteyner hatlarının finansal performanslarını finansal yapı, ödeme gücü, ciro ve karlılık kriterlerine göre değerlendirdiği çalışmasında, bulanık mantık ve gri ilişkisel analiz yöntemlerinden yararlanmıştır (Wang, 2009).

Bülbül ve Köse, Borsa İstanbul gıda endeksinde yer alan on dokuz firmanın finansal performanslarını TOPSIS ve ELECTRE yöntemleri ile karşılaştırmalı olarak değerlendirmişlerdir. Finansal performans kriterleri olarak ise likidite, faaliyet, mali yapı ve karlılık oranlarını dikkate almışlardır (Bülbül ve Köse, 2011). Balezentis vd. aktif karlılık, kaldıraç, cari, alacak devir hızı ve özsermaye karlılık oranları ve satış karı değişkenini dikkate alarak, sektörlerin finansal performanslarını değerlendirmişlerdir. Değerlendirme yöntemi olarak VIKOR, TOPSIS ve ARAS yöntemlerini bulanık mantık ile bütünleşik olarak ele almışlardır (Balezentis vd., 2012). Bayrakdaroğlu ve Yalçın, Borsa İstanbul 30 endeksinde yer alan imalat işletmelerinin finansal performanslarını değer temelli finansal kriterlere göre değerlendirmişlerdir. Ekonomik katma değer, arındırılmış ekonomik katma değer, gerçek katma değer, piyasa katma değeri, yatırımın nakit akım karlılığı ve nakit katma değer kriterlerine ilişkin kriter ağırlıklarını Bulanık AHP yöntemi ile imalat işletmelerinin finansal performans sıralamalarını ise VIKOR yöntemiyle elde etmişlerdir (Bayrakdaroğlu ve Yalçın, 2012). Lee vd. Kore ve Tayvan ülkelerinde deniz taşımacılığı yapan işletmelerin finansal performanslarını karşılaştırmalı bir şekilde ele almışlardır. Likidite, karlılık, yatırımın geri dönüşü, etkinlik, finansal kaldıraç ve nakit akışı kriterlerine ilişkin önem ağırlıklarını Entropi yöntemiyle hesaplamış, işletmelerin finansal performans sıralamalarını ise gri ilişkisel analiz yöntemiyle elde etmişlerdir (Lee vd., 2012). Yalçın vd. yedi farklı sektörde yer alan işletmelerin performanslarını değer temelli kriterler ve muhasebe temelli kriterleri dikkate alarak değerlendirmişlerdir. Bulanık AHP ile kriterlerin önem ağırlıkları hesaplanmış, VIKOR ve TOPSIS yöntemleri ile yedi sektör için ayrı ayrı olmak üzere, bu sektörlerde yer alan işletmelerin finansal performans sıralamaları karşılaştırmalı olarak gösterilmiştir (Yalçın vd., 2012).

Bakırcı vd., BIST demir çelik endeksinde yer alan on dört firmanın finansal performansını duran varlıklar, faaliyet giderleri, satışlar, faaliyet kar/zararı ve faaliyetlerden sağlanan nakit akış kriterlerine göre değerlendirmişlerdir. Veri zarflama analizi süper etkinlik sonuçları ile TOPSIS yöntemiyle elde edilen sonuçlar karşılaştırmalı şekilde sunulmuştur (Bakırc1 vd., 2014). Esbouei vd., aktif karlılığ1, özsermaye karlılı̆̆1, F/K oran1, ekonomik katma değer, piyasa katma değeri, nakit katma değer, gerçek katma değer, Tobin's Q endeksi ve hissedar değeri kriterlerini dikkate aldıkları çalışmalarında on dört sektörde yer alan toplam 143 firmanın finansal performanslarını değerlendirmişlerdir. Bulanık ANP yöntemi kriterlerin ağırlıklandırılmasında, bulanık VIKOR yöntemi ise finansal performans sıralamalarının elde edilmesinde kullanılmıştır (Esbouei vd., 2014). Ghadikolaei vd. uygulama kapsamında inceledikleri altı işletmenin finansal performansını değer temelli ve muhasebe temelli kriterleri dikkate alarak değerlendirmişlerdir. Kriterlerin önem ağırlıkları bulanık AHP yöntemiyle hesaplanmış, finansal performans sıralamaları ise bulanık VIKOR, bulanık ARAS ve bulanık COPRAS yöntemleri ile karşılaştırmalı olarak ortaya koyulmuştur (Ghadikolaei vd., 2014). Mandic vd. bankacılık sektörü için finansal performans değerlendirmesi yaptıkları çalışmalarında özsermaye, portföy, kaynaklar, likit varlıklar, nakit akışı, net faiz geliri, vergi öncesi kar ve ana faaliyet geliri kriterlerini dikkate almışlardır. Bu kriterlerin önem ağırlıklarını bulanık AHP yöntemiyle hesapladıktan sonra, TOPSIS yöntemiyle finansal performans sıralamasını elde etmişlerdir. Altı yıllık bir süreci kapsayan analiz, yıllara göre bankacılık sektöründe yer alan işletmelerin finansal performanslarını karşılaştırmalı bir şekilde değerlendirmiştir (Mandic vd., 2014). Ömürbek ve Mercan, likidite, faaliyet, karlılık ve finansal kaldıraç oranlarını dikkate aldıkları çalışmalarında 22 alt sektörden oluşan imalat sektörünün finansal performansını TOPSIS ve ELECTRE yöntemleri ile değerlendirmişlerdir. Her iki yöntem için yapılan analizler, sektörler için karşılaştırmalı bir şekilde sunulmuştur (Ömürbek ve Mercan, 2014). Tayyar vd. BIST bilişim ve teknoloji endeksinde yer alan 11 işletmenin finansal performansını AHP ve gri ilişkisel analiz yöntemlerini bütünleşik olarak ele alarak değerlendirmişlerdir. Likidite, mali yapı, faaliyet ve karlılık oranlarından oluşan finansal performans kriterlerinin önem ağırlıklarını AHP yöntemiyle hesaplayıp, gri ilişkisel analiz yöntemiyle işletmelerin finansal performans sıralamalarını elde etmişlerdir (Tayyar vd., 2014). Wang, finansal yapı, ciro, karlılık ve borç ödeme yeteneği kriterlerini dikkate alarak, taşımacılık sektöründe faaliyet gösteren işletmelerin finansal performanslarını bulanık TOPSIS yöntemiyle değerlendirmiştir. Uygulama sonuçları ile işletmelerin finansal açıdan güçlü ve zayıf olan yönlerinin tespitine yönelik bazı öneriler sunulmuştur (Wang, 2014).

Hsu vd. gri ilişkisel analize dayalı olan kriter ağırlıklandırma yöntemleri ve TOPSIS yöntemini bütünleşik olarak ele alarak teknoloji işletmelerinin finansal performanslarını değerlendirmişlerdir. Faaliyet kabiliyeti, ödeme gücü yeteneği ve karlılık kriterlerini dikkate aldıkları çalışmalarında, işletmelerin gelecek stratejilerinin belirlenmesine 
Ayçin, E., Çakın, E. / Journal of Yasar University, 2019, 14/55, 251-265

yardımcı olabilecek çözüm önerilerinde bulunmuşlardır (Hsu vd., 2015). İç vd. likidite, finansal yapı, faaliyet ve karlılık oranlarını dikkate aldıkları çalışmalarında, kurumsal 24 işletmenin finansal performans sıralamalarını TOPSIS, VIKOR, MOORA ve gri ilişkisel analiz yöntemleri ile elde etmiş̧lerdir. Ayrıca uygulama kapsamındaki işletmelerin pazar değeri sıralamaları ile ÇKKV yöntemleri ile elde edilen finansal performans sıralamaları arasında istatistiksel bir ilişkinin olup olmadığı test edilmiştir (İç vd., 2015). Kazan vd. BIST kurumsal yönetim endeksinde yer alan yedi işletmenin finansal performansını, büyüme, değer, finansal yapı, faaliyet, karlılık ve likidite oranlarına göre değerlendirmişlerdir. AHP ve PROMETHEE yöntemlerini bütünleşik olarak kullanarak, işletmelerin finansal performans sıralamalarını elde etmişlerdir (Kazan vd., 2015). Yükçü ve Kaplanoğlu BIST gıda maddeleri sanayi sektöründe yer alan işletmelerin finansal performanslarını MOORA, TOPSIS, VIKOR ve gri ilişkisel analiz yöntemleri ile analiz etmişlerdir. Borç ödeme gücü, karlılık, faaliyet kapasitesi, iş geliştirme kapasitesi, yapısal sağlamlık ve sermaye artırma kapasitesi kriterlerini dikkate aldıkları çalışmalarında 2008-2013 yılları için karşılaştırmalı olarak işletmelerin finansal performans sıralamalarını belirlemiş̧lerdir (Yükçü ve Kaplanoğlu, 2015).

Chang ve Tsai, hizmet, performans, profesyonellik, risk kontrolü ve güven kriterlerine göre bankaların finansal performanslarını değerlendirdikleri çalışmalarında AHP ve VIKOR yöntemlerini kullanmışlardır. AHP ile hesaplanan kriter ağırlıklarına göre en önemli kriterler güven ve risk kontrolü olarak belirlenmiştir. VIKOR yöntemiyle ise bankaların finansal performans sıralamaları elde edilmiş ve finansal krize yönelik önerilerde bulunulmuştur (Chang ve Tsai, 2016). Ömürbek vd. otomotiv sektöründe faaliyet gösteren işletmelerin finansal performanslarını, sermaye, hisse senedi, piyasa değeri, satış geliri, personel sayısı, net kar marjı, cari oran, özsermaye karlılığı, satı̧̧ların karlılığı ve net satı̧̧lar/personel sayısı oranı kriterlerine göre değerlendirmişlerdir. Kriterlerin önem ağırlıkları objektif bir yöntem olan Entropi ile hesaplanmıştır. Hesaplanan kriter ağıllıkları MAUT ve SAW yöntemleri ile bütünleştirilerek, işletmelerin finansal performansları karşılaştırmalı bir şekilde değerlendirilmiştir (Ömürbek vd., 2016).

Aytekin ve Karamaşa sigorta şirketlerinin finansal performanslarını değerlendirdikleri çalışmalarında cari oran, çok sınırlı likidite oranı, borç oranı, satışların karlılığı, özsermaye karlılığı ve yatıımın geri dönüşü kriterlerini dikkate almışlardır. Kriterlerin önem ağılıklarını bulanık Shannon Entropi yöntemiyle hesaplayıp, finansal performans sıralamalarını bulanık TOPSIS yöntemiyle elde etmişlerdir (Aytekin ve Karamaşa, 2017). Akçakanat vd. yaptıkları çalışmalarında, bankaların finansal performanslarını toplam aktif, toplam kredi ve alacaklar, toplam mevduat, özkaynak toplamı, şube ve personel sayısı kriterlerine göre değerlendirmişlerdir. Kriter ağırlıkları Entropi yöntemiyle hesaplandıktan sonra, WASPAS yöntemiyle bankaların performans sıralamaları elde edilmiştir (Akçakanat vd., 2017). Ünlü vd., özsermaye karlılığı, aktif karlılığı, satışların karlılı̆̆ı, faaliyet nakit akımı/varlık toplamı, piyasa katma değeri, yatırımın nakit karlılığı ve nakit katma değer kriterlerini dikkate aldıkları çalışmalarında, BIST 30 endeksinde yer alan işletmelerden kurumsal yönetim endeksi kapsamında olan ve olmayan firmaların finansal performanslarını değerlendirmişlerdir. Kriterlerin önem ağırlıklarını objektif bir değerlendirme yöntemi olan CRITIC ile hesaplayıp, TOPSIS yöntemiyle işletmelerin finansal performans sıralamalarını elde etmişlerdir. Elde edilen sonuçlar kurumsal yöntetim endeksinde yer alan ve yer almayan işletmeler için karşılaştırmalı olacak şekilde yorumlanmıştır (Ünlü vd., 2017).

Gök Kısa ve Perçin 2015 yılı itibariyle dünyanın en büyük 11 bilgisayar donanım işletmesinin finansal performansının ölçümünde, Entropi ve VIKOR yöntemlerini bütünleşik olarak kullanmışlardır. Net satışlar, varlıklar, piyasa değeri, çalş̧an sayısı, kaldıraç oranı, aktif karlılığı ve net kar marjı kriterleri dikkate aldıkları çalışmalarında, ilgili kriterlerin ağırlıklarını Entropi yöntemiyle hesaplayıp, VIKOR yöntemiyle işletmelerin finansal performans sıralamalarını elde etmişlerdir (Gök Kısa ve Perçin, 2018). Karaoğlan ve Şahin, AHP, VIKOR, TOPSIS, MOORA ve gri ilişkisel analiz yöntemlerini bütünleşik olarak kullandıkları çalışmalarında, BIST kimya endeksinde yer alan 22 işletmenin finansal performansını değerlendirmişlerdir. Likidite, finansal yapı, devir hızı ve karlılık oran kriterlerine ilişkin önem ağılıklarını AHP yöntemiyle hesapladıktan sonra, ilgili ÇKKV yöntemlerini kullanarak işletmelerin finansal performans sıralamalarını elde etmiş, karşılaştırmalı bir şekilde sonuçları değerlendirmişlerdir (Karaoğlan ve Şahin, 2018). Yıldırım vd., BIST kurumsal yönetim endeksinde yer alan 5 gıda işletmesinin finansal performansını Entropi ve TOPSIS yöntemlerini bütünleşik olarak kullanarak değerlendirmişlerdir. Likidite, devir hızı, finansal yapı, karlılık, F/K, PD/DD oranlarını kriter olarak dikkate aldıkları çalışmalarında, bu kriterlerin önem ağırlıklarını Entropi yöntemiyle hesaplayıp, finansal performans sıralamalarını ise TOPSIS yöntemiyle elde etmişlerdir. Ayrıca uygulama sonucunda elde edilen finansal performans sıralamaları ile kurumsal yönetim notları arasında istatistiksel bir ilişki olup olmadığı test edilmiş ve yorumlanmıştır (Yıldırım vd., 2018). Şahin ve Bilgin Sarı, cari oran, nakit oran, satış karlılığı, özsermaye karlılı̆̆ ve aktif devir hızı kriterlerini dikkate aldıkları çalışmalarında, BIST imalat işletmelerinin finansal performanslarını Entropi, TOPSIS ve VIKOR yöntemleri ile değerlendirmişlerdir. TOPSIS ve VIKOR yöntemleriyle elde ettikleri finansal performans sıralamaları ile işletmelerin hisse senedi getirilerine göre sıralamaları arasındaki farklılıkları istatistiki olarak test etmişlerdir (Şahin ve Bilgin Sarı, 2019). 


\section{3. МАСВЕТН}

MACBETH (Measuring Attractiveness by a Categorical-Based Evaluation Technique) yöntemi, 1976'da Keeney ve Raiffa tarafından geliştirilmiş çok nitelikli fayda teoremi üzerine dayalıdır. Çok nitelikli fayda teoreminde her bir kriter alternatiflerin kısmi faydasını göstermekte ve bu kısmi faydalar bir değer fonksiyonu ile birleştirilerek toplam fayda değeri elde edilmektedir (Cuadrado ve Fernandez, 2013: 590). MACBETH yöntemi, ilk kez Bana e Costa, Vansnick ve De Corte tarafindan 1990'lı yıllarda önerilmiş ve 11. Uluslararası Çok Kriterli Karar Verme Konferansı'nda tanıtıldıktan sonra farklı alanlarda uygulanmıştır (Kundakçı, 2016: 18).

MACBETH yöntemi, kategorik değerlendirme tekniği ile alternatiflerin göreceli çekiciliklerini ölçen bir yöntemdir. Karar vericilerin zorlanmadan tercihler arasında kalitatif değerlendirme yapmasını sağlayan ve bu değerleri nicel verilere dönüştüren bir yaklaşımdır (Bana e Costa ve Chagas, 2004: 323). Yöntemin ana amacı, değerlendirme problemleri ile ilgili etkileşimli öğrenmeyi desteklemekte ve karar verme sürecinde alternatifleri/kriterleri seçmek ve sıralamak amacıyla önerilerde bulunmaktadır. MACBETH yönteminin diğer ÇKKV yöntemlerinden fark1, alternatiflerin çekiciliklerini ölçmek için kalitatif yargıları kullanması, alternatiflerin değerlerini ve kriterlerin ağırlıklarını dikkate alarak matematiksel programlama yardımıyla alternatiflerin puanlarını hesaplayabilmesidir (Roszkowska, 2014: 69-70).

MACBETH yöntemi yedi aşamadan oluşan bir uygulama sürecine sahiptir (Kundakçı, 2016: 18-19, Carnero ve Gomez, 2016: 3-4, Karande ve Chakraborty, 2013: 262-264).

1. Aşama: İlk aşamada karar kriterleri tanımlanır ve daha sonra değer ağacı oluşturulur.

2. Aşama: Değer ağacı oluşturulduktan sonra alternatifler belirlenir. Daha sonra alternatifler her bir kritere göre ordinal performans düzeyleri tanımlanır. "100" en iyi seviye, "0" ise nötr seviye olmak üzere en az iki tane referans nokta belirlenir. Burada "100" en iyi alternatifi ya da " 0 " en kötü alternatifi temsil etmemektedir.

3. Aşama: $\mathrm{Bu}$ adımda $m$ alternatif sayısını göstermek üzere her bir kriter için $m x m$ büyüklüğünde matrisler oluşturulur. Bu matrislerde alternatifler önem düzeyine göre soldan sağa doğru sıralanır ve ordinal performans düzeyleri sayısal performans düzeylerine çevrilir. Aynı süreç kriterler için de uygulanır.

4. Aşama: Kriterler ve alternatifler için Tablo 2'de yer alan MACBETH semantik ölçeği kullanılarak ikili karşılaştırmalar yapılır.

Tablo 2. MACBETH Semantik Ölçeği

\begin{tabular}{|c|c|l|}
\hline $\begin{array}{c}\text { Semantik } \\
\text { Ölçek }\end{array}$ & $\begin{array}{c}\text { Sayısal } \\
\text { Ölçek }\end{array}$ & \multicolumn{1}{|c|}{ Açılama } \\
\hline Yok & 0 & Alternatifler arasında fark yoktur. \\
\hline Çok Zayıf & 1 & Bir alternatif diğerine göre çok zayıf derecede tercih edilir \\
\hline Zayıf & 2 & Bir alternatif diğerine göre zayıf derecede tercih edilir. \\
\hline Orta Derecede & 3 & Bir alternatif diğerine göre orta derecede tercih edilir. \\
\hline Güçlü & 4 & Bir alternatif diğerine göre güçlü derecede tercih edilir. \\
\hline Çok Güçlü & 5 & Bir alternatif diğerine göre çok güçlü derecede tercih edilir. \\
\hline Aşırı Derecede & 6 & Bir alternatif diğerine göre aşırı derecede tercih edilir. \\
\hline
\end{tabular}

5. Aşama: Karar verici tarafından yapılan ikili karşılaştırmaların tutarlılığı kontrol edilir. Eğer matris tutarsız ise MMACBETH yazılımı tarafindan yargıları tutarlı hale getirebilmek için muhtemel öneriler geliştirilir.

6. Aşama: Doğrusal programlama modeline dayalı olarak MACBETH ölçeğine göre tanımlanan yargılar uygun bir sayısal ölçeğe dönüştürülür.

7. Aşama: Son aşamada ise alternatiflerin her bir kritere göre puanları ile kriterlerin ağırlıkları çarpılıp toplanarak her bir alternatifin puanı Eşitlik (1) ve (2)'de gösterilen şekilde elde edilir.

$$
\begin{gathered}
v\left(A_{i}\right)=\sum_{j=1}^{n} w_{j}\left(v_{j}\left(A_{i}\right)\right) \\
\sum_{j=1}^{n} w_{j}=1 \quad, w_{j}>0 \quad \text { ve }\left\{\begin{array}{c}
v_{j}\left(A^{i y i}\right)=100 \\
v_{j}\left(A^{n o ̈ t r}\right)=0
\end{array}\right\}
\end{gathered}
$$

\section{COPRAS}

COPRAS yöntemi Zavadskas ve Kaklauskas tarafindan literatürde sunulan, önem ve fayda dereceleri açısından karar alternatiflerine ilişkin sıralama ve değerlendirme yapılmasını sağlayan bir ÇKKV yöntemidir. (Zavadskas vd., 1994; Kaklauskas vd., 2006).

Hem nicel hem de nitel kriterleri ele alabilen COPRAS yöntemi, karar alternatiflerin tam sıralamasının elde edilmesine olanak tanıyan bir yöntemdir (Mulliner, 2013: 274). Diğer ÇKKV yöntemlerine göre kıyaslandığında uygulama sürecinin daha kısa ve kolay olması, hesaplamaların yapılması için spesifik bilgisayar programları gerektirmemesi yöntemin en önemli avantajları olarak gösterilebilir. COPRAS yöntemi altı aşamadan oluşan bir uygulama sürecine sahiptir (Chatterjee vd., 2011: 852-853; Das vd., 2012: 7-8; Kaklauskas vd., 2007: 168-169; Özdağoğlu, 2013: 6-7). 
1. Aşama: Karar Matrisinin Oluşturulması: Yöntemin ilk aşamasında $x_{i j}$ : değerlerinden oluşan ve D ile simgelenen karar matrisi Eşitlik (3)'te gösterilen şekilde oluşturulur.

$$
D=\begin{gathered}
A_{1} \\
A_{2} \\
\vdots \\
A_{m}
\end{gathered}\left[\begin{array}{cccc}
x_{11} & x_{12} & \ldots & x_{1 n} \\
x_{21} & x_{22} & \ldots & x_{2 n} \\
\vdots & \vdots & \ldots & \vdots \\
x_{m 1} & x_{m 2} & \ldots & x_{m n}
\end{array}\right]
$$

Eşitlik (3)'te yer alan $x_{i j}$ değerleri, $j$. değerlendirme kriterine göre i. alternatifin aldığı değerleri göstermektedir $(i$, karar alternatifi sayısı $i=1,2, \ldots, m ; j$ ise değerlendirme kriteri sayısı $j=1,2, \ldots, n$ sayısı).

2. Aşama: Karar Matrisinin Normalizasyonu ve Ağırlıklandırllması: Karar problemlerindeki farklı birimlere sahip kriterlere ilişkin değerler, Eşitlik (4)’ten yararlanılarak normalize edilir.

$$
x_{i j}{ }^{*}=\frac{x_{i j}}{\sum_{i=1}^{m} x_{i j}} \quad, \forall_{j}=1,2, \ldots, n
$$

3. Aşama: Normalize Edilen Karar Matrisinin Ağırlıklandırılması: Bu aşamada her bir değerlendirme kriterinin ağırlık değeri $\left(w_{j}\right)$ ile normalize edilmiş karar matrisinin elemanları çarpılarak ağırlıklandırılmış normalize karar matrisi $\left(D^{\prime}\right)$, Eşitlik (5)’te gösterilen şekilde elde edilir.

$$
D^{\prime}=\left[\begin{array}{cccc}
d_{11} & d_{12} & \ldots & d_{1 n} \\
d_{21} & d_{22} & \ldots & d_{2 n} \\
\vdots & \vdots & \ldots & \vdots \\
d_{m 1} & d_{m 2} & \ldots & d_{m n}
\end{array}\right]
$$

Normalize edilmiş karar matrisinin ağırlıklandırılması işlemi için Eşitlik (6)'dan yararlanılmalıdır.

$$
d_{i j}=x_{i j}^{*} \cdot w_{j}
$$

Eşitlik (6)'da yer alan $d_{i j}$ değerleri, $j$. değerlendirme kriterine göre $i$. alternatifin aldığı ağırlıklandırılmış normalize değeri göstermektedir.

4. Aşama: Ağırlıklandırılmış Normalize İndekslerin Toplanması: Bu aşamada, karar probleminde yer alan kriterler için ağırlıklı normalize edilmiş karar matrisindeki değerlerin toplamı hesaplanır. Maksimizasyon (fayda) yönlü kriterler, için daha yüksek değerler daha iyi durumu göstermekte iken; minimizasyon (maliyet) yönlü kriterler için daha düşük değerler daha iyi durumu göstermektedir.

Maksimizasyon (fayda) yönlü kriterler için ağırlıklandırılmış normalize karar matrisindeki değerlerin toplamı " $\mathbf{S}_{+\mathbf{i}}$ ", minimizasyon (maliyet) yönlü kriterler için ağırlıklandırılmış normalize karar matrisindeki değerlerin toplamı ise "S $\mathbf{S}_{-\mathbf{i}}$ " ile gösterilmektedir. " $S_{+i}$ " ve " $S_{-i}$ " değerleri hesaplanırken Eşitlik (7) ve (8)'den yararlanılır.

$$
\begin{aligned}
& s_{+i}=\sum_{j=1}^{k} d_{+i j} ; j=1,2, \ldots, k \\
& s_{-i}=\sum_{j=k+1}^{n} d_{-i j} ; j=k+1, k+2, \ldots, n
\end{aligned}
$$

5. Aşama: Karar Alternatiflerinin Göreli Önem Düzeylerinin Hesaplanması: Her karar alternatifi için göreceli önem değeri anlamına gelen $Q_{i}$ değeri, Eşitlik (9)'dan yararlanılarak hesaplanır.

$$
Q_{i}=s_{+i}+\frac{s_{-\min } \sum_{i=1}^{m} s_{-i}}{s_{-i} \cdot \sum_{i=1}^{m} \frac{S_{-\min }}{S_{-i}}}
$$

Eşitlik (9) yardımıyla hesaplanan $Q_{i}$ değerlerine göre, en büyük $Q_{i}$ değerine sahip karar alternatifinin, göreceli önemi en yüksek alternatif olduğu belirlenir $\left(Q_{\text {maks }}\right)$

6. Aşama: Karar Alternatiflerinin Performans Indekslerinin Hesaplanması: Yöntemin son aşamasında, her bir karar alternatifi için performans indeks değerleri $\left(P_{i}\right)$, Eşitlik (10) yardımıyla hesaplanır.

$$
P_{i}=\frac{Q_{i}}{Q_{\text {maks }}} \cdot 100
$$

Eşitlik (10)'da $P_{i}$ ile gösterilen performans indeksi 100 olan karar alternatifi, en iyi alternatif olarak belirlenir. Performans indeks değerlerini büyükten küçüğe doğru sıralayarak, karar alternatiflerinin tercih sırasını belirlemek mümkündür. 


\section{Uygulama}

\subsection{Araştırmanın Amacı ve Yöntemi}

Bu çalışmada KOBİ’lerin finansal performanslarını ölçmeye yönelik MACBETH ve COPRAS yöntemleri kullanılarak bütünleşik bir model önerilmiştir. KOBİ'ler ülkemizin ekonomik ve sosyal kalkınmasındaki temel itici güçleridir. Bir ülkedeki KOBİ’lerin güçlü becerileri, yaptıkları katma değerli işler ülkenin kalkınmasında önemli bir destek görevi görmektedir. KOBİ'lerin sürdürülebilir bir büyüme ve gelişme göstermeleri finansal olarak sağlam temellere sahip olmalarına bağlıdır. Bu nedenle işletmelerin finansal güçlerini belirlemeleri ve finansal performans düzeylerini hem rakipleri ile hem de yıllar itibariyle karşılaştırarak mevcut durumlarını ortaya koymalı ve analiz sonuçlarına göre de geleceğe yönelik çeşitli önlemleri almalıdırlar. Bu kapsamda ülkemiz için büyük öneme sahip olan KOBİlerin finansal performansları analiz edilmiş ve KOBİ Endeksinde yer alan işletmeler analiz kapsamına alınmıştır. Ayrıca finansal performans değerlendirmesi sadece KOBİ'ler için değil aynı zamanda yatırımcılar, fon sağlayıcılar ve paydaşlar için de önemli bir konu olarak karşımıza çıkmaktadır. Analize dahil edilen KOBİ Endeksinde yer alan işletmelerin finansal verileri KAP'ın internet sitesinden elde edilmiş ve finansal oranlara çevrilerek analizler yapılmıştır. Çalışma kapsamında MACBETH yöntemi ile kriterlerin ağırlıklandırılması sürecinde karar verici olarak KOSGEB'de görev yapan üç KOBİ uzmanının görüşlerine başvurulmuştur. Hem literatürden elde edilen bilgiler hem de uzmanların görüşleri neticesinde Tablo 3'de yer alan kriterler dikkate alınmıştır.

Tablo 3. Çalışma Kapsamında Dikkate Alınan Kriterler

\begin{tabular}{|c|l|l|}
\hline Kriter No & \multicolumn{1}{|c|}{ Kriter Adı } & \multicolumn{1}{c|}{ Hesaplama } \\
\hline 1 & Cari Oran (CO) & Dönen Varlık/KVYK \\
\hline 2 & Nakit Oran (NO) & (Hazır Değerler+Menkul Kıymetler)/KVYK \\
\hline 3 & Dönen Varlık Devir Hızı Oranı (DÖVDHO) & Net Satışlar/Dönen Varlıklar \\
\hline 4 & Duran Varlık Devir Hızı Oranı (DUDHO) & Net Satışlar/Duran Varlıklar \\
\hline 5 & Özsermaye Devir Hızı Oranı (ÖDHO) & Net Satışlar/Özsermaye \\
\hline 6 & Kaldıraç Oranı (KO) & (KVYK+UVYK)/Toplam Aktif \\
\hline 7 & Özsermaye Karlılık Oranı (ÖKO) & Net Kar/Özsermaye \\
\hline 8 & Aktif Karlılık Oranı (AKO) & Net Kar/Toplam Aktif \\
\hline 9 & Satışların Karlılık Oranı (SKO) & Net Kar/ Net Satışlar \\
\hline
\end{tabular}

Kriter ağırlıkları uzman görüşleri ile belirlendikten sonra Tablo 4'de yer alan BIST KOBİ Endeksinde işlem gören işletmelerin finansal performansları değerlendirilecektir.

Tablo 4. Çalışma Kapsamında Finansal Performansı Ölçülen İşletme Listesi

\begin{tabular}{|c|c|}
\hline İşletme Kodu & $\begin{array}{ll}\text { İşletme Adı } \\
\end{array}$ \\
\hline ACSEL & ACISELSAN ACIPAYAM SELÜLOZ SANAYİ VE TİCARET A.Ş. \\
\hline BRMEN & BİRLİK MENSUCAT TİCARET VE SANAYİ İSSLETMESİ A.Ș. \\
\hline BURVA & BURÇELIKK VANA SANAYİ VE TİCARET A.Ş. \\
\hline DIRIT & DİRITTEKS DİRİLIŞ TEKSTİL SANAYİ VE TİCARET A.Ş. \\
\hline DOGUB & DOĞUSAN BORU SANAYIII VE TİCARET A.Ş. \\
\hline ERSU & ERSU MEYVE VE GIDA SANAYİ A.Ș. \\
\hline IZTAR & İZ HAYVANCILIK TARIM VE GIDA SANAYİ TİCARET A.Ș. \\
\hline IZFAS & İZMİR FIRÇA SANAYİ VE TİCARET A.Ş. \\
\hline MEGAP & MEGA POLİETİLEN KÖPÜK SANAYİ A.Ş. \\
\hline NIBAS & NIĞBAŞ NIĞDE BETON SANAYİ VE TİCARET A.Ş. \\
\hline OYLUM & OYLUM SINAİ YATIRIMLAR A.Ş. \\
\hline OZRDN & ÖZERDEN PLASTİK SANAYİ VE TİCARET A.Ş. \\
\hline POLTK & POLİTEKNİK METAL SANAYİ VE TİCARET A.Ş. \\
\hline PRZMA & PRİZMA PRES MATBAACILIK YAYINCILIK SANAYİ VE TİCARET A.Ș. \\
\hline RODRG & RODRİGO TEKSTİL SANAYİ VE TİCARET A.Ș. \\
\hline RTALB & RTA LABORATUVARLARI BİYOLOJIK ÜRÜNLER İLAÇ VE MAKİNA SANAYİ TİCARET A.Ş. \\
\hline SEYKM & SEYİTLER KİMYA SANAYİ A.Ş. \\
\hline TACTR & TAÇ TARIM ÜRÜNLERİ HAYVANCILIK GIDA SANAYİ VE TİCARET A.Ş. \\
\hline TKURU & TAZE KURU GIDA SANAYİ VE TİCARET A.Ș. \\
\hline VANGD & VANET GIDA SANAYİ İÇ VE DIȘ TİCARET A.Ș. \\
\hline YAPRK & YAPRAK SÜT VE BESİ ÇİFTLİKLERİ SANAYİ VE TİCARET A.Ș. \\
\hline
\end{tabular}

\subsection{MACВETH Yöntemi İle Kriterlerin Ăğırlıklandırılması}

Kriterlerin ağırlıklandırılması için üç farklı uzmandan Tablo 3'de yer alan kriterleri MACBETH ölçeği kullanarak karşılaştırması istenmiştir. Her bir uzman görüşlerinden elde edilen kriter ağırlıklarının ortalaması alınarak her bir kriterin ağırlığı hesaplanmıştır. MACBETH yöntemi ile kriter ağırlıklarının hesaplanması sürecinde M-MACBETH programından faydalanılmıştır. MACBETH ile kriter ağırlıklarının elde edilebilmesi için öncelikle değer ağacı 
Ayçin, E., Çakın, E. / Journal of Yasar University, 2019, 14/55, 251-265

oluşturulmuş ve bu değer ağacından faydalanılarak ikili karşılaştırma matrisleri elde edilmiştir. Şekil 1 ve Şekil 2’de birinci karar vericinin görüşlerine dayalı olarak oluşturulan değer ağacı, karar matrisi ve kriter ağırlıkları yer almaktadır.

Şekil 1. Karar Verici-1 İçin Oluşturulan Değer Ağacı

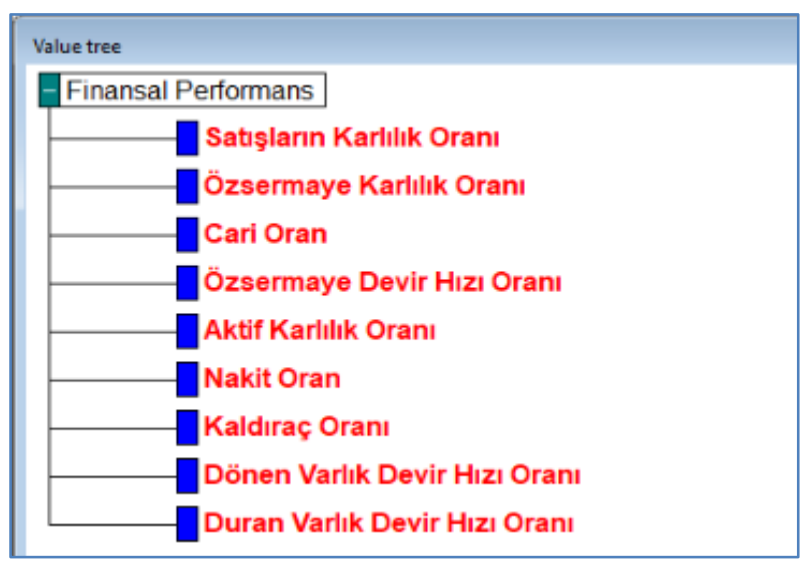

Şekil 2. Karar Verici-1 Tarafından Oluşturulan İkili Karşılaştırma Matrisi ve Kriter Ağırlıkları

\begin{tabular}{|c|c|c|c|c|c|c|c|c|c|c|c|c|}
\hline \multicolumn{11}{|c|}{ Meight Weing (Finansal Performans) } & \multirow[b]{2}{*}{$\begin{array}{c}\text { Current } \\
\text { scalo }\end{array}$} & \multirow{3}{*}{$\begin{array}{l}\text { extreme } \\
\text { v. strong }\end{array}$} \\
\hline 图 & [SKO] & [ ŌKO] & {$[\mathrm{CO}]$} & [ŌDHO] & [AKO] & [NO] & {$[\mathrm{KO}]$} & [DÓVDHO ] & [DUVDHO ] & [ all lower ] & & \\
\hline [SKO ] & no & very weak & vweak-weak & weak & weak-mod & moderate & moderate & strong & v. strong & postive & 15.23 & \\
\hline [ $0 \mathrm{OKO}]$ & & no & weak & weak-mod & moderate & weak-mod & weak-mod & mod-strg & vstrg-extr & postive & 14.97 & moderate \\
\hline$[\mathrm{CO}]$ & & & no & weak & weak & moderate & mod-strg & mod-strg & strg-vstr & postive & 14.47 & weak \\
\hline [OOHO] & & & & no & weak-mod & mod-strg & mod-strg & strong & strg-vstr & postive & 13.96 & very weak \\
\hline [AKO ] & & & & & no & mod-strg & weak-str & strg-vstr & v. strong & postive & 13.45 & no \\
\hline [NO] & & & & & & no & mod-strg & strong & v. strong & postive & 11.93 & \\
\hline [ KO ] & & & & & & & no & strg-vstr & vstrg-extr & postive & 10.41 & \\
\hline$[$ DOVDHO ] & & & & & & & & no & strg-extr & postive & 5.33 & \\
\hline [ DUVDHO] & & & & & & & & & no & postive & 0.25 & \\
\hline [al lower] & & & & & & & & & & no & 0.00 & \\
\hline \multicolumn{13}{|c|}{ Consistent judgements } \\
\hline 国 & 818 & 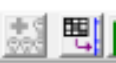 & Inftant & 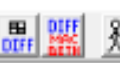 & ? & & & & & & & \\
\hline
\end{tabular}

Şekil 2'deki kriter ağırlıklarına bakıldığında, 1. karar vericiye göre en önemli kriterler satışların karlılık oranı, özsermaye karlılık oranı ve cari oran, en az öneme sahip kriterler ise duran varlık devir hızı oranı, dönen varlık devir hızı oranı ve kaldıraç oranı değişkenleridir. Diğer karar vericiler için de benzer süreçler ile kriterler karşılaştırılmış ve sonuçlar Tablo 5'de gösterilmiştir. Her bir karar vericiye göre elde edilen kriter ağırlıklarının ortalaması alınarak grup kararına dayalı olarak kriter ağırlıkları hesaplanmıştır.

Tablo 5. Karar Vericilerin Görüşlerine Göre Elde Edilen Kriter Ağırlıkları

\begin{tabular}{|c|c|c|c|c|}
\hline Kriterler & Karar Verici 1 & Karar Verici 2 & Karar Verici 3 & Ortalama \\
\hline Satışların Karlılık Oranı & 0,152 & 0,171 & 0,157 & $\mathbf{0 , 1 6 0}$ \\
\hline Özsermaye Karlılık Oranı & 0,149 & 0,109 & 0,145 & $\mathbf{0 , 1 3 4}$ \\
\hline Cari Oran & 0,144 & 0,157 & 0,168 & $\mathbf{0 , 1 5 6}$ \\
\hline Özsermaye Devir Hızı Oranı & 0,139 & 0,061 & 0,075 & $\mathbf{0 , 0 9 2}$ \\
\hline Aktif Karlılık Oranı & 0,134 & 0,185 & 0,174 & $\mathbf{0 , 1 6 4}$ \\
\hline Nakit Oran & 0,119 & 0,200 & 0,122 & $\mathbf{0 , 1 4 7}$ \\
\hline Kaldıraç Oranı & 0,104 & 0,057 & 0,110 & $\mathbf{0 , 0 9 0}$ \\
\hline Dönen Varlık Devir Hızı Oranı & 0,053 & 0,052 & 0,005 & $\mathbf{0 , 0 3 7}$ \\
\hline Duran Varlık Devir Hızı Oranı & 0,002 & 0,004 & 0,040 & $\mathbf{0 , 0 1 5}$ \\
\hline
\end{tabular}

Tablo 5 incelendiğinde; en fazla öneme sahip kriterlerin aktif karlılık oranı, satışların karlılık oranı ve cari oran, en az öneme sahip kriterlerin de duran varlık devir hızı oranı, dönen varlık devir hızı oranı ve kaldıraç oranıdır.

\subsection{COPRAS Yöntemi İle Finansal Performans Ölçümü}

MACBETH yöntemiyle Tablo 3'te gösterilen kriterlere ilişkin önem ağırlıkları elde edildikten sonra, uygulamanın bu aşamasında Tablo 4'te gösterilen işletmelerin finansal performansları değerlendirilecektir. Bu doğrultuda ele alınan 
Ayçin, E., Çakın, E. / Journal of Yasar University, 2019, 14/55, 251-265

işletmelerin, Kamuoyu Aydınlanma Platformu (KAP)'na bildirdikleri 2018 yllı en son dönemine ait finansal tablolarından yararlanılarak finansal oranları hesaplanmıştır. Hesaplanan finansal oranlar Tablo 6'da gösterilmektedir.

Tablo 6. İşletmelerin Finansal Oranları

\begin{tabular}{|l|c|c|c|c|c|c|c|c|c|}
\hline $\begin{array}{c}\text { İşletmeler/ } \\
\text { Kriterler }\end{array}$ & CO & NO & DÖVDHO & DUDHO & ÖDHO & KO & ÖKO & AKO & SKO \\
\hline ACSEL & 3,310 & 0,050 & 0,796 & 0,764 & 1,109 & 0,204 & 0,145 & 0,051 & 0,131 \\
\hline BRMEN & 0,133 & 4,935 & 0,388 & 0,028 & 0,125 & 0,509 & $-0,257$ & $-0,054$ & $-2,052$ \\
\hline BURVA & 1,441 & 0,093 & 0,323 & 1,399 & 0,574 & 0,685 & 0,009 & 0,004 & 0,015 \\
\hline DIRIT & 1,135 & 0,122 & 0,323 & 0,120 & 0,216 & 0,575 & $-0,198$ & $-0,080$ & $-0,915$ \\
\hline DOGUB & 0,438 & 0,140 & 0,437 & 0,105 & 0,093 & 0,531 & $-0,047$ & $-0,043$ & $-0,504$ \\
\hline ERSU & 3,022 & 0,003 & 0,262 & 0,144 & 0,137 & 0,196 & 0,008 & 0,005 & 0,058 \\
\hline IZTAR & 0,773 & 0,057 & 0,807 & 0,320 & 1,394 & 0,535 & 0,131 & 0,021 & 0,094 \\
\hline IZFAS & 2,132 & 0,509 & 0,419 & 7,306 & 1,192 & 0,618 & $-0,013$ & $-0,004$ & $-0,011$ \\
\hline MEGAP & 3,958 & 2,048 & 0,852 & 5,012 & 1,157 & 0,230 & 0,067 & 0,042 & 0,058 \\
\hline NIBAS & 0,638 & 0,217 & 0,644 & 0,262 & 0,440 & 0,514 & $-0,207$ & $-0,087$ & $-0,470$ \\
\hline OYLUM & 1,023 & 0,271 & 0,934 & 0,571 & 1,416 & 0,545 & $-0,097$ & $-0,024$ & $-0,068$ \\
\hline OZRDN & 1,752 & 0,768 & 1,184 & 1,515 & 1,647 & 0,433 & 0,170 & 0,069 & 0,104 \\
\hline POLTK & 4,879 & 5,277 & 0,959 & 3,994 & 6,868 & 0,186 & 1,174 & 0,132 & 0,171 \\
\hline PRZMA & 4,941 & 0,242 & 0,167 & 0,154 & 0,146 & 0,119 & 0,000 & 0,000 & 0,001 \\
\hline RODRG & 2,005 & 0,270 & 0,434 & 0,940 & 0,861 & 0,549 & 0,154 & 0,053 & 0,179 \\
\hline RTALB & 6,424 & 33,278 & 0,287 & 0,426 & 0,444 & 0,101 & 0,001 & 0,001 & 0,003 \\
\hline SEYKM & 2,786 & 5,616 & 0,527 & 0,814 & 0,970 & 0,243 & 0,097 & 0,032 & 0,100 \\
\hline TACTR & 0,483 & 0,009 & 0,490 & 0,102 & 0,409 & 0,511 & 0,044 & 0,009 & 0,108 \\
\hline TKURU & 2,652 & 0,130 & 0,426 & 1,207 & 2,089 & 0,715 & $-0,435$ & $-0,066$ & $-0,208$ \\
\hline VANGD & 8,046 & 4,750 & 0,046 & 0,069 & 0,061 & 0,096 & 0,077 & 0,035 & 1,263 \\
\hline YAPRK & 1,163 & 0,700 & 0,985 & 0,411 & 1,696 & 0,396 & 0,407 & 0,070 & 0,240 \\
\hline
\end{tabular}

COPRAS yöntemi ile çözüme başlamadan önce, normalizasyon aşamasındaki hesaplamalarda yanlışlık olmaması amacıyla, karlılık oranlarında yer alan negatif değerler Z-skoru standartlaştırma dönüşümü kullanılarak düzeltilmiştir. Bu düzeltme işlemi için Eşitlik (11) ve (12)'den yararlanılmalıdır.

$$
\begin{gathered}
z_{i j}=\frac{x_{i j}-\bar{X}_{j}}{\sigma_{j}} \\
z_{i j}^{\prime}=z_{i j}+A ; \quad A>\left|\min z_{i j}\right|
\end{gathered}
$$

Düzeltme işlemi yapıldıktan sonra COPRAS yöntemi için başlangıç aşamasını oluşturacak karar matrisi Tablo 7'deki gibi elde edilmiştir.

Tablo 7. Karar Matrisi

\begin{tabular}{|l|c|c|c|c|c|c|c|c|c|}
\hline $\begin{array}{c}\text { İşletmeler/ } \\
\text { Kriterler }\end{array}$ & CO & NO & DÖVDHO & DUDHO & ÖDHO & KO & ÖKO & AKO & SKO \\
\hline ACSEL & 3,310 & 0,050 & 0,796 & 0,764 & 1,109 & 0,204 & 1,804 & 3,554 & 6,844 \\
\hline BRMEN & 0,133 & 4,935 & 0,388 & 0,028 & 0,125 & 0,509 & 2,109 & 3,859 & 7,149 \\
\hline BURVA & 1,441 & 0,093 & 0,323 & 1,399 & 0,574 & 0,685 & 2,285 & 4,035 & 7,325 \\
\hline DIRIT & 1,135 & 0,122 & 0,323 & 0,120 & 0,216 & 0,575 & 2,175 & 3,925 & 7,215 \\
\hline DOGUB & 0,438 & 0,140 & 0,437 & 0,105 & 0,093 & 0,531 & 2,131 & 3,881 & 7,171 \\
\hline ERSU & 3,022 & 0,003 & 0,262 & 0,144 & 0,137 & 0,196 & 1,796 & 3,546 & 6,836 \\
\hline IZTAR & 0,773 & 0,057 & 0,807 & 0,320 & 1,394 & 0,535 & 2,135 & 3,885 & 7,175 \\
\hline IZFAS & 2,132 & 0,509 & 0,419 & 7,306 & 1,192 & 0,618 & 2,218 & 3,968 & 7,258 \\
\hline MEGAP & 3,958 & 2,048 & 0,852 & 5,012 & 1,157 & 0,230 & 1,830 & 3,580 & 6,870 \\
\hline NIBAS & 0,638 & 0,217 & 0,644 & 0,262 & 0,440 & 0,514 & 2,114 & 3,864 & 7,154 \\
\hline OYLUM & 1,023 & 0,271 & 0,934 & 0,571 & 1,416 & 0,545 & 2,145 & 3,895 & 7,185 \\
\hline OZRDN & 1,752 & 0,768 & 1,184 & 1,515 & 1,647 & 0,433 & 2,033 & 3,783 & 7,073 \\
\hline POLTK & 4,879 & 5,277 & 0,959 & 3,994 & 6,868 & 0,186 & 1,786 & 3,536 & 6,826 \\
\hline PRZMA & 4,941 & 0,242 & 0,167 & 0,154 & 0,146 & 0,119 & 1,719 & 3,469 & 6,759 \\
\hline RODRG & 2,005 & 0,270 & 0,434 & 0,940 & 0,861 & 0,549 & 2,149 & 3,899 & 7,189 \\
\hline RTALB & 6,424 & 33,278 & 0,287 & 0,426 & 0,444 & 0,101 & 1,701 & 3,451 & 6,741 \\
\hline SEYKM & 2,786 & 5,616 & 0,527 & 0,814 & 0,970 & 0,243 & 1,843 & 3,593 & 6,883 \\
\hline TACTR & 0,483 & 0,009 & 0,490 & 0,102 & 0,409 & 0,511 & 2,111 & 3,861 & 7,151 \\
\hline TKURU & 2,652 & 0,130 & 0,426 & 1,207 & 2,089 & 0,715 & 2,315 & 4,065 & 7,355 \\
\hline VANGD & 8,046 & 4,750 & 0,046 & 0,069 & 0,061 & 0,096 & 1,696 & 3,446 & 6,736 \\
\hline YAPRK & 1,163 & 0,700 & 0,985 & 0,411 & 1,696 & 0,396 & 1,996 & 3,746 & 7,036 \\
\hline
\end{tabular}


Ayçin, E., Çakın, E. / Journal of Yasar University, 2019, 14/55, 251-265

Tablo 7'deki karar matrisi Eşitlik (4)'ten yararlanılarak normalize edilir. Normalize edilen karar matrisi Tablo 8'de gösterilmiş̧ir. 
Ayçin, E., Çakın, E. / Journal of Yasar University, 2019, 14/55, 251-265

Tablo 8. Normalize Karar Matrisi

\begin{tabular}{|l|c|c|c|c|c|c|c|c|c|}
\hline $\begin{array}{c}\text { İşletmeler/ } \\
\text { Kriterler }\end{array}$ & CO & NO & DÖVDHO & DUDHO & ÖDHO & KO & ÖKO & AKO & SKO \\
\hline ACSEL & 0,0623 & 0,0008 & 0,0681 & 0,0298 & 0,0481 & 0,0240 & 0,0429 & 0,0451 & 0,0463 \\
\hline BRMEN & 0,0025 & 0,0830 & 0,0332 & 0,0011 & 0,0054 & 0,0600 & 0,0501 & 0,0490 & 0,0483 \\
\hline BURVA & 0,0271 & 0,0016 & 0,0276 & 0,0545 & 0,0249 & 0,0807 & 0,0543 & 0,0512 & 0,0495 \\
\hline DIRIT & 0,0214 & 0,0021 & 0,0276 & 0,0047 & 0,0094 & 0,0677 & 0,0517 & 0,0498 & 0,0488 \\
\hline DOGUB & 0,0082 & 0,0024 & 0,0373 & 0,0041 & 0,0040 & 0,0625 & 0,0506 & 0,0492 & 0,0485 \\
\hline ERSU & 0,0569 & 0,0001 & 0,0224 & 0,0056 & 0,0060 & 0,0231 & 0,0427 & 0,0450 & 0,0462 \\
\hline IZTAR & 0,0145 & 0,0010 & 0,0690 & 0,0125 & 0,0605 & 0,0630 & 0,0507 & 0,0493 & 0,0485 \\
\hline IZFAS & 0,0401 & 0,0086 & 0,0359 & 0,2847 & 0,0517 & 0,0728 & 0,0527 & 0,0503 & 0,0491 \\
\hline MEGAP & 0,0745 & 0,0344 & 0,0729 & 0,1953 & 0,0502 & 0,0271 & 0,0435 & 0,0454 & 0,0464 \\
\hline NIBAS & 0,0120 & 0,0036 & 0,0551 & 0,0102 & 0,0191 & 0,0605 & 0,0502 & 0,0490 & 0,0484 \\
\hline OYLUM & 0,0193 & 0,0046 & 0,0799 & 0,0223 & 0,0614 & 0,0642 & 0,0510 & 0,0494 & 0,0486 \\
\hline OZRDN & 0,0330 & 0,0129 & 0,1013 & 0,0590 & 0,0715 & 0,0509 & 0,0483 & 0,0480 & 0,0478 \\
\hline POLTK & 0,0918 & 0,0887 & 0,0821 & 0,1556 & 0,2980 & 0,0219 & 0,0424 & 0,0449 & 0,0461 \\
\hline PRZMA & 0,0930 & 0,0041 & 0,0143 & 0,0060 & 0,0063 & 0,0140 & 0,0408 & 0,0440 & 0,0457 \\
\hline RODRG & 0,0377 & 0,0045 & 0,0371 & 0,0366 & 0,0374 & 0,0646 & 0,0510 & 0,0494 & 0,0486 \\
\hline RTALB & 0,1209 & 0,5594 & 0,0246 & 0,0166 & 0,0193 & 0,0119 & 0,0404 & 0,0438 & 0,0456 \\
\hline SEYKM & 0,0524 & 0,0944 & 0,0451 & 0,0317 & 0,0421 & 0,0286 & 0,0438 & 0,0456 & 0,0465 \\
\hline TACTR & 0,0091 & 0,0002 & 0,0419 & 0,0040 & 0,0177 & 0,0602 & 0,0502 & 0,0490 & 0,0483 \\
\hline TKURU & 0,0499 & 0,0022 & 0,0364 & 0,0470 & 0,0907 & 0,0842 & 0,0550 & 0,0516 & 0,0497 \\
\hline VANGD & 0,1514 & 0,0799 & 0,0040 & 0,0027 & 0,0027 & 0,0113 & 0,0403 & 0,0437 & 0,0455 \\
\hline YAPRK & 0,0219 & 0,0118 & 0,0843 & 0,0160 & 0,0736 & 0,0467 & 0,0474 & 0,0475 & 0,0476 \\
\hline
\end{tabular}

Bir sonraki aşamada Tablo 8'de gösterilen normalize karar matrisi, kriterlerin önem ağırlıkları ile çarpılarak ağırlıklandırılmış normalize karar matrisi elde edilmelidir. Uygulamanın ilk bölümünde MACBETH yöntemiyle hesaplanan ve Tablo 5'te gösterilmiş olan kriterlerin önem ağırlıkları, Eşitlik (6)'dan yararlanılarak normalize karar matrisin her bir elemanı ile çarpılır. Böylece ağırlıklandırılmış normalize karar matrisi Tablo 9'daki gibi elde edilir.

Tablo 9. Ağırlıklandırılmış Normalize Karar Matrisi

\begin{tabular}{|l|c|c|c|c|c|c|c|c|c|}
\hline $\begin{array}{c}\text { İsletmeler/ } \\
\text { Kriterler }\end{array}$ & CO & NO & DÖVDHO & DUDHO & ÖDHO & KO & ÖKO & AKO & SKO \\
\hline ACSEL & 0,0097 & 0,0001 & 0,0025 & 0,0004 & 0,0044 & 0,0022 & 0,0057 & 0,0074 & 0,0074 \\
\hline BRMEN & 0,0004 & 0,0122 & 0,0012 & 0,0000 & 0,0005 & 0,0054 & 0,0067 & 0,0080 & 0,0077 \\
\hline BURVA & 0,0042 & 0,0002 & 0,0010 & 0,0008 & 0,0023 & 0,0073 & 0,0073 & 0,0084 & 0,0079 \\
\hline DIRIT & 0,0033 & 0,0003 & 0,0010 & 0,0001 & 0,0009 & 0,0061 & 0,0069 & 0,0082 & 0,0078 \\
\hline DOGUB & 0,0013 & 0,0003 & 0,0014 & 0,0001 & 0,0004 & 0,0056 & 0,0068 & 0,0081 & 0,0078 \\
\hline ERSU & 0,0089 & 0,0000 & 0,0008 & 0,0001 & 0,0005 & 0,0021 & 0,0057 & 0,0074 & 0,0074 \\
\hline IZTAR & 0,0023 & 0,0001 & 0,0026 & 0,0002 & 0,0056 & 0,0057 & 0,0068 & 0,0081 & 0,0078 \\
\hline IZFAS & 0,0063 & 0,0013 & 0,0013 & 0,0043 & 0,0048 & 0,0066 & 0,0071 & 0,0083 & 0,0079 \\
\hline MEGAP & 0,0116 & 0,0051 & 0,0027 & 0,0029 & 0,0046 & 0,0024 & 0,0058 & 0,0074 & 0,0074 \\
\hline NIBAS & 0,0019 & 0,0005 & 0,0020 & 0,0002 & 0,0018 & 0,0054 & 0,0067 & 0,0080 & 0,0077 \\
\hline OYLUM & 0,0030 & 0,0007 & 0,0030 & 0,0003 & 0,0057 & 0,0058 & 0,0068 & 0,0081 & 0,0078 \\
\hline OZRDN & 0,0051 & 0,0019 & 0,0037 & 0,0009 & 0,0066 & 0,0046 & 0,0065 & 0,0079 & 0,0076 \\
\hline POLTK & 0,0143 & 0,0130 & 0,0030 & 0,0023 & 0,0274 & 0,0020 & 0,0057 & 0,0074 & 0,0074 \\
\hline PRZMA & 0,0145 & 0,0006 & 0,0005 & 0,0001 & 0,0006 & 0,0013 & 0,0055 & 0,0072 & 0,0073 \\
\hline RODRG & 0,0059 & 0,0007 & 0,0014 & 0,0005 & 0,0034 & 0,0058 & 0,0068 & 0,0081 & 0,0078 \\
\hline RTALB & 0,0189 & 0,0822 & 0,0009 & 0,0002 & 0,0018 & 0,0011 & 0,0054 & 0,0072 & 0,0073 \\
\hline SEYKM & 0,0082 & 0,0139 & 0,0017 & 0,0005 & 0,0039 & 0,0026 & 0,0059 & 0,0075 & 0,0074 \\
\hline TACTR & 0,0014 & 0,0000 & 0,0016 & 0,0001 & 0,0016 & 0,0054 & 0,0067 & 0,0080 & 0,0077 \\
\hline TKURU & 0,0078 & 0,0003 & 0,0013 & 0,0007 & 0,0083 & 0,0076 & 0,0074 & 0,0085 & 0,0080 \\
\hline VANGD & 0,0236 & 0,0117 & 0,0001 & 0,0000 & 0,0002 & 0,0010 & 0,0054 & 0,0072 & 0,0073 \\
\hline YAPRK & 0,0034 & 0,0017 & 0,0031 & 0,0002 & 0,0068 & 0,0042 & 0,0064 & 0,0078 & 0,0076 \\
\hline
\end{tabular}

Tablo 9'daki hesaplanan değerler yardımıla, ağırlıklandırılmış normalize indeks değerlerinin toplamları hesaplanacaktır. Bu hesaplama yapılırken maksimizasyon yönlü kriterler için Eşitlik (7), minimizasyon yönlü kriterler için ise Eşitlik (8)'den yararlanılmalıdır. Uygulama kapsamındaki kriterlerden yalnızca kaldıraç oranı minimizasyon yönlü bir kriter iken, diğer sekiz kriter maksimizasyon yönlüdür. Kriter yönleri dikkate alınarak yapılan hesaplamalar sonucu elde edilen değerler Tablo 10'da gösterilmiştir. 
Ayçin, E., Çakın, E. / Journal of Yasar University, 2019, 14/55, 251-265

Tablo 10. Ağırlıklandırılmış Normalize İndeks Toplamları

\begin{tabular}{|l|c|c|}
\hline \multicolumn{1}{|c|}{ İşletmeler } & $\boldsymbol{S}_{+\boldsymbol{i}}$ & $\boldsymbol{S}_{-\boldsymbol{i}}$ \\
\hline ACSEL & 0,0378 & 0,0022 \\
\hline BRMEN & 0,0368 & 0,0054 \\
\hline BURVA & 0,0322 & 0,0073 \\
\hline DIRIT & 0,0285 & 0,0061 \\
\hline DOGUB & 0,0261 & 0,0056 \\
\hline ERSU & 0,0308 & 0,0021 \\
\hline IZTAR & 0,0334 & 0,0057 \\
\hline IZFAS & 0,0410 & 0,0066 \\
\hline MEGAP & 0,0476 & 0,0024 \\
\hline NIBAS & 0,0289 & 0,0054 \\
\hline OYLUM & 0,0353 & 0,0058 \\
\hline OZRDN & 0,0402 & 0,0046 \\
\hline POLTK & 0,0806 & 0,0020 \\
\hline PRZMA & 0,0363 & 0,0013 \\
\hline RODRG & 0,0346 & 0,0058 \\
\hline RTALB & 0,1239 & 0,0011 \\
\hline SEYKM & 0,0489 & 0,0026 \\
\hline TACTR & 0,0272 & 0,0054 \\
\hline TKURU & 0,0423 & 0,0076 \\
\hline VANGD & 0,0556 & 0,0010 \\
\hline YAPRK & 0,0370 & 0,0042 \\
\hline
\end{tabular}

COPRAS yönteminin son aşamasında öncelikle karar alternatiflerinin göreli önem düzeyleri $\left(Q_{i}\right)$ Eşitlik (9) yardımıyla hesaplanır. Daha sonra $Q_{i}$ değerleri kullanılarak karar alternatiflerinin performans indeksleri $\left(P_{i}\right)$ ise Eşitlik (10) yardımıyla hesaplanarak, finansal performansı en iyi işletmeler belirlenir. Yapılan hesaplamalar sonucunda elde edilen değerler Tablo 11 'de gösterilmiştir.

Tablo 11. COPRAS Yöntemi Sonuçları

\begin{tabular}{|l|c|c|c|}
\hline \multicolumn{1}{|c|}{ İşletmeler } & $\mathbf{Q}_{\mathbf{i}}$ & $\mathbf{P}_{\mathbf{i}}$ & Sıralama \\
\hline ACSEL & 0,0435 & 32,11 & 8 \\
\hline BRMEN & 0,0391 & 28,86 & 12 \\
\hline BURVA & 0,0339 & 25,01 & 17 \\
\hline DIRIT & 0,0305 & 22,52 & 19 \\
\hline DOGUB & 0,0283 & 20,86 & 21 \\
\hline ERSU & 0,0368 & 27,15 & 14 \\
\hline IZTAR & 0,0355 & 26,23 & 16 \\
\hline IZFAS & 0,0429 & 31,68 & 10 \\
\hline MEGAP & 0,0527 & 38,90 & 5 \\
\hline NIBAS & 0,0311 & 22,98 & 18 \\
\hline OYLUM & 0,0375 & 27,65 & 13 \\
\hline OZRDN & 0,0429 & 31,69 & 9 \\
\hline POLTK & $\mathbf{0 , 0 8 6 9}$ & $\mathbf{6 4 , 1 1}$ & $\mathbf{2}$ \\
\hline PRZMA & 0,0461 & 34,06 & 6 \\
\hline RODRG & 0,0368 & 27,14 & 15 \\
\hline RTALB & $\mathbf{0 , 1 3 5 5}$ & $\mathbf{1 0 0 , 0 0}$ & $\mathbf{1}$ \\
\hline SEYKM & 0,0537 & 39,62 & 4 \\
\hline TACTR & 0,0295 & 21,74 & 20 \\
\hline TKURU & 0,0439 & 32,41 & 7 \\
\hline VANGD & $\mathbf{0 , 0 6 7 9}$ & $\mathbf{5 0 , 0 8}$ & $\mathbf{3}$ \\
\hline YAPRK & 0,0400 & 29,51 & 11 \\
\hline
\end{tabular}

COPRAS yöntemiyle elde edilen performans indeksleri ve sıralamalar Tablo 11'de gösterilmektedir. Uygulama sonuçlarına göre finansal performansı en iyi olan işletmenin RTA Laboratuvarları Biyolojik Ürünler İlaç ve Makina Sanayi Ticaret A.Ş. olduğu tespit edilmiştir. Bu işletmeyi sırasıyla Politeknik Metal Sanayi ve Ticaret A.Ş ile Vanet Gıda Sanayi İç ve Dış Ticaret A.Ş. takip etmektedir. Finansal performansı en kötü olan işletmeler ise Doğusan Boru Sanayi ve Ticaret A.Ş., Taç Tarım Ürünleri Hayvancılık Gıda Sanayi ve Ticaret A.Ş. ve Diriteks Diriliş Tekstil Sanayi ve Ticaret A.Ş. olarak belirlenmiştir. 


\section{Sonuç Ve Öneriler}

Ülkemizde faaliyet gösteren işletmelerin sayısal olarak çoğunluğunu oluşturan KOBİler, sağladıkları istihdam olanakları, ürettikleri katma değer yaratan ürünler ve ekonomik gelişimde oynadıkları roller bakımından önemli ekonomik birimlerdir. Bu işletmelerin günümüz artan rekabet ortamında güçlü bir şekilde faaliyetlerini sürdürüp, ekonomik olarak büyümeleri için finansal performanslarını en yüksek düzeye çekmeleri gerekmektedir. Dolayısıyla finansal performans göstergelerin düzenli olarak en doğru şekilde analiz edilip yorumlanması önem arz etmektedir.

Bu çalışmada BIST KOBİ endeksinde yer alan işletmelerin finansal performanslarının değerlendirilmesine yönelik bir uygulama, ÇKKV karar verme yöntemlerinden bütünleşik olarak yararlanılarak gerçekleştirilmiştir. İşletmelerin likidite, faaliyet, finansal ve karlılık göstergelerine ait olacak şekilde belirlenen dokuz adet performans kriteri, subjektif bir ÇKKV yöntemi olan MACBETH ile değerlendirilmiştir. MACBETH yöntemi ile kriterlerin ağırlıklandırılması sürecinde karar verici olarak KOSGEB'de görev yapan üç KOBİ uzmanının görüşlerine başvurularak, ilgili ağırlıklar hesaplanmıştır. MACBETH yöntemiyle elde edilen sonuçlara göre en fazla öneme sahip kriterlerin aktif karlılık oranı, satışların karlılık oranı ve cari oran olduğu en az öneme sahip kriterlerin de duran varlık devir hızı oranı, dönen varlık devir hızı oranı ve kaldıraç oranı olduğu belirlenmiştir. Bu kapsamda KOBİ'ler için en önemli kriterler dikkate alınarak o kriterlere diğer kriterlerden daha fazla önem verilmesi gerektiği açıktır. Örneğin; aktif karlılığı ya da satış karlılığ1 diğer işletmelere göre düşük olan bir işletme gerekli önlemleri alarak gelecek dönemde bu konulara önem vermesi gerekmektedir. Ayrıca işletme zayıf olduğu noktaları güçlendirmek için üretim, pazarlama, Ar-Ge vb. gibi işletmenin diğer birimleri ile etkileşimli bir şekilde yeni uygulamaları ve yöntemleri hayata geçirebilmelidir. Böylelikle KOBİ'ler düzenli olarak finansal performanslarını değerlendirerek çok zaman kaybetmeden gerekli tedbirleri alarak sürdürülebilir bir gelişme gösterebilir. Finansal performans değerlendirme neticesinde elde edilen analiz sonuçları gelecek için KOBİler için önemli bir bilgi kaynağı olabilmektedir.

Kriter ağırlıkları hesaplandıktan sonra, bir başka ÇKKV yöntemi olan COPRAS ile finansal performans değerlendirilerek, işletmelere ilişkin bir performans sıralaması elde edilmiştir. COPRAS yöntemiyle elde edilen sonuçlara göre finansal performansı en iyi olan işletmeler sırasıyla RTA Laboratuvarları Biyolojik Ürünler İlaç ve Makina Sanayi Ticaret A.Ş., Politeknik Metal Sanayi ve Ticaret A.Ş ile Vanet Gida Sanayi İç ve Dış Ticaret A.Ş. olarak belirlenmiştir. Finansal performansı en kötü olan işletmeler ise Doğusan Boru Sanayi ve Ticaret A.Ş., Taç Tarım Ürünleri Hayvancılık Gıda Sanayi ve Ticaret A.Ş. ve Diriteks Diriliş Tekstil Sanayi ve Ticaret A.Ş. olarak sıralanmıştır.

Mevcut çalışmada, subjektif bir yöntem olan ve literatürde nispeten az yer alan MACBETH yöntemi finansal performans kriterlerinin değerlendirilmesinde, bir diğer ÇKKV yöntemi olan COPRAS ise finansal performans sıralamasının belirlenmesinde kullanılmıştır. Bu açıdan bakıldığında mevcut çalışmanın literatüre katkı sağladığ 1 düşünülmektedir. Gelecek çalışmalarda KOBİlerin finansal performans değerlendirmeleri, daha farklı ÇKKV yöntemlerinin bütünleşik olarak kullanılmasıyla gerçekleştirilebilir. Böylece daha farklı yöntemler ile elde edilen sonuçlar, mevcut uygulamanın sonuçları ile karşılaştırılarak öneriler geliştirilebilir. Ayrıca performans kriterlerinin önem ağırlıkları belirlenirken objektif kriter ağırlıklandırma yöntemlerinden yararlanılabilir. Böylece subjektif ve objektif yöntemler kullanılarak gerçekleştirilen çalışmalar arasında bir kıyaslama imkanı doğacaktır.

MACBETH yöntemi ile kriter ağırlıkları hesaplananabildiği gibi, karar alternatifi ya da kriterlerin sıralamalarını da elde etmek mümkündür. M-MACBETH yazılımı ile ikili karşılaştırmaların kolay bir şekilde yapılması ve tutarsızlıkların program tarafindan tespit edilmesi, kullanıcıya kolaylık sağlamaktadır. Dolayısıyla subjektif değerlendirmelerin yapıldığı karar problemlerinde, MACBETH yönteminin gelecek çalışmalarda daha sıklıkla kullanılabileceği düşünülmektedir. 
Ayçin, E., Çakın, E. / Journal of Yasar University, 2019, 14/55, 251-265

\section{KAYNAKÇA}

Akçakanat, Ö., Eren, H., Aksoy, E., Ömürbek, V. (2017), "Bankacıllk Sektöründe Entropi ve WASPAS Yöntemleri İle Performans Değerlendirmesi”, Süleyman Demirel Üniversitesi İktisadi ve İdari Bilimler Fakültesi Dergisi, 22(2), 285-300.

Apan, M., Oztel, A., Islamoglu, M. (2017), “An Assessment of the Paper Industry Firms Listed in Borsa Istanbul Using Entropy-Based MAUT Method”. Financial Environment and Business Development (pp. 15-28). Springer.

Aras, G., Tezcan, N., Furtuna, O. K. (2018), "Multidimensional comprehensive corporate sustainability performance evaluation model: Evidence from an emerging market banking sector", Journal of Cleaner Production, 185, 600-609.

Aytekin, A., Karamaşa, Ç. (2017), “Analyzing Financial Performance Of Insurance Companies Traded In BIST via Fuzzy Shannon's Entropy Based Fuzzy TOPSIS Methodology”, Alphanumeric Journal, 5(1), 51-84.

Bakırcı, F., Shiraz, S. E., Sattary, A. (2014), "BIST Demir, Çelik Metal Ana Sanayii Sektöründe Faaliyet Gösteren İşletmelerin Finansal Performans Analizi: VZA Süper Etkinlik ve TOPSIS Uygulaması", Ege Akademik Bakış, 14(1), 9-19.

Baležentis, A., Baležentis, T., Misiūnas, A. (2012), "An Integrated Assessment of Lithuanian Economic Sectors Based on Financial Ratios and Fuzzy MCDM Methods", Technological and Economic Development of Economy, 18(1), 34-53.

Bana E. Costa, C.A. ve Chagas, M.P. (2004), "A Career Choice Problem: An Example of How to Use MACBETH to Build a Quantitative Value Model Based on Qualitative Value Judgments", European Journal of Operational Research, 153, 323-331.

Bayrakdaroğlu, A., Yalçın, N. (2012), Strategic Financial Performance Evaluation of the Turkish Companies Traded on ISE, Ege Akademik Bakış, 12(4), 529-539.

Bülbül, S., Köse, A. (2011), "Türk Gıda Şirketlerinin Finansal Performansının Çok Amaçlı Karar Verme Yöntemleriyle Değerlendirilmesi”, Atatürk Üniversitesi İktisadi ve İdari Bilimler Dergisi 10. Ekonometri ve İstatistik Sетровуити Özel Saylsl, 71-97.

Carnero, M.C. ve Gómez, A. (2016), "A Multicriteria Decision Making Approach Applied to Improving Maintenance Policies in Healthcare Organizations", BMC Medical Informatics and Decision Making, 16 (47), 1-22.

Cuadrado, M.R. ve Fernández, M.G. (2013), "Methodology to Select the Best Business Game in Higher Education", American Journal of Industrial and Business Management, 3, 589-594

Çelen, A. (2014), "Comparative Analysis of Normalization Procedures in TOPSIS Method: With an Application to Turkish Deposit Banking Market" Informatica, 25(2), 185-208.

Chang, S. C., Tsai, P. H. (2016), "A Hybrid Financial Performance Evaluation Model for Wealth Management Banks Following the Global Financial Crisis", Technological and Economic Development of Economy, 22(1), 21-46.

Chatterjee, P. Athawale, V. M. Chakraborty, S. (2011), "Materials selection using complex proportional assessment and evaluation of mixed data methods", Materials and Design, 32, 851-860

Das, M. C., Sarkar, B., \& Ray, S. (2012). A framework to measure relative performance of Indian technical institutions using integrated fuzzy AHP and COPRAS methodology. Socio-Economic Planning Sciences, 46(3), 230-241.

Ergül, N. (2014), "BİST- Turizm Sektöründeki Şirketlerin Finansal Performans Analizi", Çankırı Karatekin Üniversitesi İktisadi ve İdari Bilimler Fakültesi Dergisi, 4(1), 325-340.

Ertuğrul, İ., Karakaş̧oğlu, N. (2009), "Performance Evaluation of Turkish Cement Firms with Fuzzy Analytic Hierarchy Process and TOPSIS Methods", Expert Systems with Applications, 36(1), 702-715.

Esbouei, S. K., Ghadikolaei, A. S., Antucheviciene, J. (2014), "Using FANP and Fuzzy VIKOR for Ranking Manufacturing Companies Based On Their Financial Performance", Economic Computation \& Economic Cybernetics Studies \& Research, 48(3), 141-162.

Ghadikolaei, A. S., Esbouei, S. K., Antucheviciene, J. (2014), "Applying Fuzzy MCDM for Financial Performance Evaluation of Iranian Companies", Technological and Economic Development of Economy, 20(2), 274-291.

Gök-Kisa, A. C., Perçin, S. (2018), "Bütünleşik Entropi Ağıllık-VIKOR Yöntemi İle Bilişim Teknolojisi Sektöründe Performans Ölçümü”. Ekonomik ve Sosyal Araştırmalar Dergisi, 14(1), 1-13.

Hsu, L. C., Ou, S. L., Ou, Y. C. (2015), “A Comprehensive Performance Evaluation and Ranking Methodology under a Sustainable Development Perspective, Journal of Business Economics and Management, 16(1), 74-92.

İç, Y. T., Tekin, M., Pamukoğlu, F. Z., Yildirim, S. E. (2015), "Kurumsal Firmalar İçin Bir Finansal Performans Karşlaştırma Modelinin Geliştirilmesi”, Gazi Üniversitesi Mühendislik-Mimarlık Fakültesi Dergisi, 30(1), 7185.

Inani, S. K., Gupta, R. (2017), "Evaluating financial performance of Indian IT firms: an application of a multi-criteria decision-making technique", International Journal of Behavioural Accounting and Finance, 6(2), 126-139.

Kaklauskas, A. Zavadskas, E.K. Trinkunas, V. (2007), "A Multiple Criteria Decision Support On-Line System For Construction", Engineering Applications of Artificial Intelligence, 20, 163-175.

Kaklauskas, A., Zavadskas, E. K., Raslanas, S., Ginevicius, R., Komka, A., Malinauskas, P. (2006). Selection of Low-e Windows in Retrofit of Public Buildings by Applying Multiple Criteria Method COPRAS: A Lithuanian Case. Energy and Buildings, 38(5), 454-462.

Karande, P. ve Chakraborty, S. (2014), "Using MACBETH Method for Supplier Selection in Manufacturing Environment", International Journal of Industrial Engineering Computations, 4, 259-272 
Ayçin, E., Çakın, E. / Journal of Yasar University, 2019, 14/55, 251-265

Karaoğlan, S., Şahin, S. (2018). BİST XKMYA İşletmelerinin Finansal Performanslarının Çok Kriterli Karar Verme Yöntemleri İle Ölçümü ve Yöntemlerin Karş1laştırılması, Ege Akademik Bakış, 18(1), 63-80.

Kazan, H., Ertok, M., Ciftçi, C. (2015), "Application of a Hybrid Method in the Financial Analysis of Firm Performance", Procedia-Social and Behavioral Sciences, 195, 403-412.

Kumar, R. R., Kumar, C. (2017), "Designing an efficient methodology based on Entropy-TOPSIS for evaluating efficiency of cloud services", In Proceedings of the 7th International Conference on Computer and Communication Technology (pp. 117-122). ACM.

Kundakçı, N. (2016), "Combined Multi-Criteria Decision Making Approach Based On MACBETH And MultiMOORA Methods", Alphanumeric Journal, 4(1), 17-26

Lee, P. T. W., Lin, C. W., Shin, S. H., (2012), “A Comparative Study on Financial Positions of Shipping Companies in Taiwan and Korea using Entropy and Grey Relation Analysis”, Expert Systems with Applications 39(5), 56495657.

Mandic, K., Delibasic, B., Knezevic, S., Benkovic, S. (2014), “Analysis of the Financial Parameters of Serbian Banks through the Application of the Fuzzy AHP and TOPSIS Methods", Economic Modelling, 43, 30-37.

Masca, M. (2017), "Economic Performance Evaluation of European Union Countries by Topsis Method", North Economic Review, 1(1), 83-94.

Mulliner, E., Smallbone K. \& Maliene V. (2013). An Assessment of Sustainable Housing Affordability using a Multiple Criteria Decision Making Method. Omega, 41(2), 270-279.

Ömürbek, N., Karaatli, M., Balci, H. F. (2016), "Entropi Temelli MAUT ve SAW Yöntemleri ile Otomotiv Firmalarının Performans Değerlemesi”, Dokuz Eylül Üniversitesi Iktisadi ve İdari Bilimler Fakültesi Dergisi, 31(1), 227255.

Ömürbek, N., Mercan, Y. (2014), “İmalat Alt Sektörlerinin Finansal Performanslarının TOPSIS ve ELECTRE Yöntemleri İle Değerlendirilmesi”, Çankırı Karatekin Üniversitesi İIBF Dergisi, 4(1), 237-266.

Özdağoğlu, A. (2013). Çok Ölçütlü Karar Verme Modellerinde Normalizasyon Tekniklerinin Sonuçlara Etkisi: COPRAS Örneği. Eskişehir Osmangazi Üniversitesi İktisadi ve İdari Bilimler Dergisi, 8(2), 229-252.

Roszkowska, E. (2014), "The MACBETH Approach for Evaluation Offers in Ill-Structure Negotiations Problems", Optimum Studia Ekonomıczne, 5 (71), 69-88.

Safaei Ghadikolaei, A., Khalili Esbouei, S., \& Antucheviciene, J. (2014), “Applying Fuzzy MCDM for Financial Performance Evaluation of Iranian Companies", Technological and Economic Development of Economy, 20(2), 274-291.

Seçme, N. Y., Bayrakdaroğlu, A., Kahraman, C. (2009), "Fuzzy Performance Evaluation in Turkish Banking Sector Using Analytic Hierarchy Process and TOPSIS", Expert Systems with Applications, 36(9), 11699-11709.

Sermaye Piyasasi Kurulu (SPK), (2016), "Menkul Kıymet Yatırım Ortaklıkları", www.spk.gov.tr ; Erişim Tarihi: 30/08/2018.

Şahin, A., Bilgin Sarı, E. (2019), “Entropi Tabanlı Topsis ve Vikor Yöntemleriyle Bist İmalat İşletmelerinin Finansal ve Borsa Performanslarının Karşılaştırılması”, Muhasebe ve Vergi Uygulamaları Dergisi, 12 (2), 255-270.

Tayyar, N., Akcanli, F., Genç, E., Erem, I. (2014). “BIST’e Kayıtlı Bilişim ve Teknoloji Alanında Faaliyet Gösteren İşletmelerin Finansal Performanslarının Analitik Hiyerarşi Prosesi (AHP) ve Gri İlişkisel Analiz (GİA) Yöntemiyle Değerlendirilmesi", Muhasebe ve Finansman Dergisi, (61), 19-40.

Ünlü, Ü., Yalçın, N., Yağlı, İ. (2017), "Kurumsal Yönetim ve Firma Performansı: TOPSIS Yöntemi İle BIST 30 Firmaları Üzerine Bir Uygulama”, Dokuz Eylül Üniversitesi Sosyal Bilimler Enstitüsü Dergisi, 19(1), 63-81.

Wang, Y. J. (2008), “Applying FMCDM to Evaluate Financial Performance of Domestic Airlines in Taiwan”, Expert Systems with Applications, 34(3), 1837-1845.

Wang, Y. J. (2009), "Combining Grey Relation Analysis with FMCGDM to Evaluate Financial Performance of Taiwan Container Lines", Expert Systems with Applications, 36(2), 2424-2432.

Wang, Y. J. (2014), "The Evaluation of Financial Performance for Taiwan Container Shipping Companies by Fuzzy TOPSIS", Applied Soft Computing, 22, 28-35.

Wang, Y. J., Lee, H. S. (2010), "Evaluating Financial Performance of Taiwan Container Shipping Companies by Strength and Weakness Indices", International Journal of Computer Mathematics, 87(1), 38-52.

Wang, Y. J., Lee, H. S. (2010), "Evaluating Financial Performance of Taiwan Container Shipping Companies by Strength and Weakness Indices", International Journal of Computer Mathematics, 87(1), 38-52.

Wang, Y-J. (2008), "Applying FMCDM to Evaluate Financial Performance of Domestic Airlines in Taiwan", Expert Systems with Applications, 34, 1837-1845.

Wang, Y-J. (2009), "Combining Grey Relation Analysis with FMCGDM to Evaluate Financial Performance of Taiwan Container Lines", Expert Systems with Applications, 36: 2424-2432.

Wang, Y-J., Lee, H-S. (2010), "Evaluating Financial Performance of Taiwan Container Shipping Companies by Strength and Weakness Indices", International Journal of Computer Mathematics, 87(1), 38-52.

Yalçın, N., Bayrakdaroğlu, A., Kahraman, C. (2012), "Application of Fuzzy Multi-Criteria Decision Making Methods for Financial Performance Evaluation of Turkish Manufacturing Industries", Expert Systems with Applications, 39, 350-364.

Yıldırım, M., Altan, İ. M., \& Gemici, R. (2018), "Evaluation of the Relationship between Corporate Governance and Financial Performance by Entropy Based TOPSIS Method: A Study on Food and Beverage Companies Traded on the Istanbul Stock Exchange (BIST)", Muhasebe ve Vergi Uygulamalar Dergisi, 11(2), 130-152. 
Ayçin, E., Çakın, E. / Journal of Yasar University, 2019, 14/55, 251-265

Yükçü, S., Kaplanoğlu, E. (2015), "Çok Kriterli Karar Verme Yöntemleriyle Gözaltı Pazarı Şirketlerinin Finansal Performanslarının Belirlenmesi", World of Accounting Science, 17(3), 687-616.

Zavadskas, E. K., Kaklauskas, A., Sarka, V. (1994). The new method of multicriteria complex proportional assessment of projects, Technological and Economic Development of Economy, 1(3): 131-139. 